\title{
Hegemoni Korporasi di Lumbung Jagung (Studi Kasus Petani Jagung di Kec. Lopok Kab. Sumbawa)
}

\author{
Junaidi $^{1}$, Sumitro ${ }^{2}$ \\ Prodi Pendidikan Sosiologi, Universitas Muhammadiyah Makassar \\ Email : kaharuddin@unismuh.ac.id \\ Dosen Fakultas IImu Budaya, Institut IImu Sosial dan IImu Budaya Samawa Rea \\ Email : junaidiadiguna@gmail.com
}

\begin{abstract}
In the last few years, Sumbawa Island has been busy with the issue of fraudulent logging. In some media, several hectares of forest on Sumbawa Island have been damaged due to fraudulent logging and have turned into corn fields. So it is undeniable that the cause of flooding on the island of Sumbawa is due to the forest being encroached on to plant corn. For this reason, expanding the corn planting area into forest areas must be controlled. Expansion of land for maize crops by encroaching on forests can lead to various environmental problems. From the problem of flooding in the rainy season, to the problem of drought in the dry season. In this study, photographing changes in farmer behavior due to hegemony/coorporate control (maize distributors) is not very visible society in this area. This type of research uses descriptive qualitative. This research was conducted on corn farmers in Mamak village as part of the community whose profession as farmers. The research location will be in Mamak Village, Lopok District, Sumbawa Regency, West Nusa Tenggara Province. Data collection techniques used observation, interviews and documentation. The validity of the data using source triangulation. Data analysis techniques with data collection, data reduction, data presentation, and conclusions. The results of this study indicate the social impact on farmers in the form of difficulties in adapting farmers to newly developed agricultural commodities. The next impact is a change in the behavior of farmers who tend to do logging on the forest. The forms of corporate hegemony that occur in Sumbawa include; First, the corporate hegemony towards farmers as the main provider of corn commodities. The second is the corporate hegemony against the government which is unable to fully control the market mechanism. Farmers in Sumbawa are not aware of the exploitation of land and labor used by corporations to increase the number of corn commodities. Farmers only understand that efforts to increase corn production are intended to improve their standard of living. Farmers consider the corn planting program to be part of the local government's economic improvement program without realizing the corporate interests behind this program.
\end{abstract}

Keywords : Hegemony, Corporation, Corn Farmer.

Beberapa tahun terakhir pulau Sumbawa disibukkan dengan isu pembalakan liar, dibeberapa media menjelaskan sekian banyak hektar hutan di pulau Sumbawa rusak akibat pembalakan liar dan beralih fungsi menjadi ladang jagung. Sehingga tak bisa dipungkiri penyebab banjir di pulau Sumbawa akibat hutan yang dirambah untuk menanam jagung. Untuk itu, perluasan areal tanam jagung ke kawasan hutan harus dikendalikan. Perluasan lahan tanaman jagung dengan melakukan perambahan hutan dapat memunculkan berbagai masalah lingkungan. Dari masalah banjir dimusim hujan, hingga masalah kekeringan di musim kemarau. Dalam penelitian ini memotret perubahan perilaku petani akibat hegemoni/penguasaan koorporasi (distributor Jagung) tidak begitu terlihat dominasinya, Petani Jagung di kecamatan lopok adalah salah satu potret yang mewakili hegemoni koorporasi hasil jagung di kabupaten Sumbawa, untuk itu perlu untuk dilakukan penelilitian lebih jauh untuk mendeskripsikan masalah sosial yang ada di daerah ini. Jenis penelitian menggunakan deskriptif kualitatif. Penelitian ini dilakukan terhadap petani jagung di desa Mamak sebagai 
bagian dari masyarakat yang profesi sebagai petani. Lokasi penelitian akan berada di desa Mamak kecamatan Lopok Kabupaten Sumbawa Propinsi Nusa Tenggara Barat. Teknik pengumpulan data menggunakan observasi, wawancara dan dokumentasi. Keabsahan data menggunakan triangulasi sumber. Teknik analisis data dengan pengumpulan data, reduksi data, penyajian data, dan kesimpulan. Hasil penelitian ini menunjukkan dampak sosial terhadap petani berupa kesulitan adaptasi petani terhadap komoditi pertanian yang baru dikembangkan. Dampak selanjutnya berupa perubahan perilaku petani yang cenderung melakukan pembalakan terhadap hutan. Adapun bentuk hegemoni koorporasi yang terjadi di Sumbawa antara lain; Pertama hegemoni korporasi terhadap petani sebagai penyedia utama komoditas jagung. Kedua hegemoni korporasi terhadap pemerintah yang tidak mampu mengontrol sepenuhnya mekanisme pasar. Petani di Sumbawa tidak menyadari eksploitasi terhadap lahan dan tenaga yang digunakan pihak korporasi untuk meningkatkan jumlah komoditas Jagung. Petani hanya memahami bahwa upaya peningkatan produksi jagung dimaksudkan untuk meningkatkan taraf hidupnya. Petani menganggap program penanaman jagung merupakan bagian dari program peningkatan ekonomi dari pemerintah daerah tanpa menyadari kepentingan koorporasi dibalik program ini.

Kata Kunci : Hegemoni, Korporasi, Petani Jagung.

\section{PENDAHULUAN}

Beberapa tahun terakhir pulau Sumbawa disibukkan dengan isu pembalakan liar, dibeberapa media menjelaskan sekian banyak hektar hutan di pulau Sumbawa rusak akibat pembalakan liar dan beralih fungsi menjadi ladang jagung. Kabupaten Sumbawa bagian timur, Dompu, Bima akan menjadi langganan banjir tiap tahun pasalnya, 75 persen kawasan hutan yang rusak di NTB berada di Pulau Sumbawa. Kepala dinas lingkungan hidup (LHK) NTB, Ir. Madani Mukarom, B. Sc.F, M.Si yang dikonfirmasi Suara NTB, Kamis, 4 April 2019 siang menyatakan banjir bandang yang terjadi diwilayah Dompu, Bima, maupun Sumbawa bagian timur akibat kondisi hutan yang memprihatinkan. Catatan dinas LHK NTB, jumlah lahan Kritis mencapai 280.941 Hektar dan kawasan terbuka seluas 131.991 Hektar (Http:///www.suarantb.com). Kepala dinas lingkungan hidup (LHK) NTB tak memungkiri penyebab banjir di pulau Sumbawa akibat hutan yang dirambah untuk menanam jagung. Untuk itu, perluasan areal tanam jagung ke kawasan hutan harus dikendalikan. Perluasan lahan tanaman jagung dengan melakukan perambahan hutan dapat memunculkan berbagai masalah lingkungan. Dari masalah banjir dimusim hujan, hingga masalah kekeringan di musim kemarau.

Kebijakan pemerintah yang berprioritas pada pertumbuhan ekonomi semata tanpa mempertimbangkan kondisi sosial masyarakat maupun kondisi lingkungan. Pada kasus eksploitasi hutan seolah-olah pelaku tunggal dari pengrusakan adalah masyarakat. Padahal dua pihak lain yaitu pemerintah dan pihak korporasi sejatinya ikut bertanggungjawab. Dimana program penanaman jagung adalah paket kebijakan antara pemerintah dan pihak korporasi yang membeli jagung dari masyarakat. Sehingga dalam kasus alih fungsi lahan dari hutan masyarakat hanya mengikuti kebutuhan pasar, dimana Jagung dibutuhkan dalam jumlah banyak otomatis masyarakat sebagai mahluk ekonomi tertarik untuk menanam jagung karena keuntungannya menggiurkan. Namun nyatanya alih alih petani jagung mendapatkan keuntungan besar, justru harga jagung menjadi anjlok karena jumlah barang yang terlalu banyak. Kondisi ini diperparah lagi dengan munculnya makelar yang membeli jagung langsung ke petani dengan harga yang rendah, kadang hasil jagung dibeli dengan harga dibawah standar harga yang ditetapkan oleh pemerintah.

Bupati Sumbawa - HM Husni Djibril mengaku bersyukur karena para petani di Kecamatan Moyo Utara dapat melakukan Panen Raya Jagung dengan luas areal panen mencapai 3.000 hektar, meningkat signifikan dari hanya 600 hektar pada tahun 2016 lalu. Adapun produksi jagung dari hasil panen raya diperkirakan mencapai 27.000 ton. Hal ini tentunya menjadi motivasi sekaligus memberikan harapan dan semangat baru bagi semua pihak, terutama Pemerintah Daerah, karena berbagai program pembangunan, pembinaan dan pendanaan yang telah diupayakan bagi masyarakat petani dapat membuahkan hasil (Pulau Sumbawa News, 2018). Begitulah kutipan 
harapan pemerintah 2 tahun lalu terhadap komoditi jagung di Kab. Sumbawa. namun hasilnya kini harus dipertanyakan kembali apakah masih sesuai harapan atau tidak?

"Ibarat jatuh tertimpa tangga pula" begitulah ungkapan yang bisa menggambarkan kondisi petani jagung saat ini. Iming-iming kemakmuran dari hasil jagung yang melimpah justru membawa banyak masalah baru. Demi mencapai hasil jagung dalam jumlah besar petani melakukan pembukaan lahan dengan merambah hutan, hasilnya curah hujan menurun dan kekeringan melanda daerah mereka. Karena curah hujan rendah dan kekeringan yang panjang, lahan pertanian yang semula ditanami padi kini terpaksa ditanami tanaman yang tahan panas, dan jagung kembali menjadi pilihan masyarakat. Tanaman jagung yang awalnya bertujuan sebagai komoditi sampingan untuk petani kini menjadi komoditi utama, lama kelamaan petani menggantungkan hidupnya pada komoditi jagung.

Kondisi ketergantungan semacam ini oleh Antonio Gramsci disebut Hegemoni. hegemoni adalah sebagai suatu dominasi kekuasaan suatu kelas sosial atas kelas sosial lainnya, melalui kepemimpinan intelektual dan moral yang dibantu dengan dominasi atau penindasan. Hegemoni merujuk pada kesetujuan, penanaman kekuasaan yang dilakukan dengan kesepakatan dari kelas yang dikuasai/didominasi, dan penerimaan yang ikhlas/sukarela dari kelas itu (Damanik, 2019). Petani Jagung disini sebagai pihak yang dikuasai sedangkan korporasi sebagai pihak yang menguasai.

Hegemoni berbeda dengan dominasi, dimana hegemoni menuntut penerimaan ikhlas/sukarela dari kelas yang dikuasai. Dalam penelitian ini lokasi Kecamatan Lopok diambil karena penguasaan koorporasi (distributor Jagung) tidak begitu terlihat dominasinya, namun nyatanya di kecamatan ini terdapat 3 gudang jagung yang beroperasi. Petani Jagung di kecamatan lopok adalah salah satu potret yang mewakili hegemoni koorporasi hasil jagung di kabupaten Sumbawa, untuk itu perlu untuk dilakukan penelilitian lebih jauh untuk mendeskripsikan masalah sosial yang ada di daerah ini.

\section{METODE}

Jenis penelitian yang digunakan dalam penelitian ini adalah penelitian deskriptif kualitatif. Menurut Bogdan dan Taylor, metodologi kualitatif adalah prosedur penelitian yang menghasilkan data deskriptif berupa kata-kata tertulis dari orang-orang dan perilaku yang dapat diamati (Moleong, 2002:3). Deskriptif kualitatif yaitu dengan mendeskripsikan kualitas suatu gejala yang menggunakan ukuran perasaan sebagai dasar penilaian, penelitian deskriptif bermaksud untuk memberikan uraian mengenai suatu gejala sosial yang diteliti. Peneliti mendeskripsikan suatu gejala berdasarkan pada indikator-indikator yang dia jadikan dasar dari ada tidaknya suatu gejala yang dia teliti (Slamet, 2006:7). Metode kualitatif dapat digunakan untuk mempelajari, membuka dan mengerti apa yang terjadi di belakang setiap fenomena yang baru sedikit diketahui. Oleh karena itu metode penelitian yang digunakan dalam penelitian ini adalah metode penelitian kualitatif. Penelitian ini menggambarkan bentuk hegemoni koorporasi terhadap keberlangsungan kehidupan sosial dan ekonomi petani jagung di Kecamatan Lopok. Penelitian ini dilakukan terhadap petani jagung di desa Mamak sebagai bagian dari masyarakat yang profesi sebagai petani. Lokasi penelitian akan berada di desa Mamak kecamatan Lopok Kabupaten Sumbawa Propinsi Nusa Tenggara Barat.

Alasan peneliti mengambil lokasi penelitian ini adalah Kecamatan lopok memiliki wilayah hutan yang cukup luas, memiliki danau buatan (bendugan Mamak) sebagai sumber utama pengairan, dan memiliki sawah dan ladang yang ditanami jagung. Hal-hal tersebut merupakan ekosistem penunjang pertanian, sehingga petani di wilayah ini bisa merasa langsung dampak sosial maupun ekonomi dari kerusakan ekosistem yang ditimbulkan dari produksi masal tanaman jagung. Masyarakat tani di wilayah ini memenuhi kriteria mewakili wilayah lain di Kabupeten Sumbawa untuk kebutuhan penelitian studi kasus ini. Sumber data yang digunakan peneliti dalam penelitian ini dibedakan menjadi; a. data Primer dan b. data sekunder. Untuk data primer, informasi yang akan digali dalam penelitian ini berupa data-data yang digali dari para perani berupa kondisi sosial ekonomi masyarakat Kecamatan Lopok Kabupaten Sumbawa. Sedangkan untuk data sekunder berupa data- 
data statistik kependudukan di Kecamatan Lopok terkait kondisi sosial ekonomi dan tingkat kerusakan kawasan hutan lindung di Kabupaten Sumbawa. Populasi atau Universe adalah jumlah keseluruhan dari unit analisis (Slamet, 2006:40). Populasi merupakan jumlah tertentu dari individu yang akan diselidiki oleh peneliti. Populasi dalam penelitian ini adalah masyarakat kecamatan Lopok Kabupaten Sumbawa. sedangkan sampel yang diambil dari populasi dalam penelitian ini bukan sesuatu yang mutlak. Artinya sampel yang akan diambil menyesuaikan dengan kebutuhan di lapangan.

Dalam penelitian ini sampel berfungsi untuk menggali beragam informasi dan menemukan sejauh mungkin informasi penting. Jumlah sampel dalam penelitian ini sebanyak 9 orang, yang diambil menggunakan teknik purposive sampling atau sampling bertujuan. Sampel diambil berdasarkan tiga kategori (1) petani dengan kategori miskin, (2) petani dengan kategori ekonomi menengah dan (3) petani dengan kategori kaya. Pengkategorian ini berdasarkan data statistik sosial ekonomi masyarakat yang ada di Kecamatan Lopok hasil sensus tahun 2019. Pemilihan sampel berdasarkan kemampuan ekonomi ini dilakukan untuk mendapatkan tanggapan yang beragam mengenai peran koorporasi dalam memainkan harga jagung dipasaran dan peran pemerintah dalam penetuan kebijakan untuk progam pertanian jagung di kecamatan Lopok. Penelitian ini menggunakan teknik triangulasi dalam mencapai validitas data. Teknik triangulasi adalah teknik penarikan keabsahan data dengan memanfaatkan penggunaan sesuatu yang lain di luar data itu untuk keperluan penyelesaian atau sebagai pembanding terhadap data yang sudah ada. Dimana dalam penelitian ini menggunakan triangulasi sumber. Artinya membandingkan dan mengecek kembali derajat kepercayaan suatu sumber informasi yang diperoleh melalui waktu dan alat yang berbeda dalam metode kualitatif. Pada penelitian ini peneliti bekerja dengan data atau dengan teknik analisa data interactive of analysis yang mempunyai tahap-tahap sebagai berikut : a. Pengumpulan Data (Data Collection), b. Reduksi Data (Data Reduction), c. Penyajian Data (Data Display), d. Penarikan Kesimpulan (Conclusions)

\section{HASIL PENELITIAN DAN PEMBAHASAN}

Melihat sejauhmana pengaruh hegemoni korporasi pada masyarakat Kecamatan Lopok, dimulai dengan melihat bagaimana gejala-gejala sosial sebagai dampak dari hadir dan beroperasinya korporasi di daerah ini. Pada paparan hasil penelitian ini pada mulanya akan membahas tentang dampak sosial dari peningkatan jumlah ladang jagung di kecamatan Lopok. Selanjutnya diikuti dengan pembahasan bentuk hegemoni korporasi terhadap masyarakat (petani) dan birokrasi.

\section{A. Ringkasan Temuan hasil wawancara}

Dari pengakuan seluruh informan, program pertanian jagung sudah berlangsung 3-5 tahun. Dalam rentang waktu tersebut diakui sudah banyak lahan baru yang dibuka selama program jagung ini dimulai (pembukaan lahan yang sebelumnya berisi tanaman kayu). Selain pembukaan lahan baru, Tanah persawahan juga digunakan untuk penanaman jagung selepas musim penghujan, namun kontur tanahnya kurang sesuai dengan tanaman ini karena, teralu basah, meski ditanam pada musim kemarau. Hal ini dilakukan oleh petani yang lahannya kurang akhirnya membuka lahan baru.

Salah seorang dari informan merupakan petani baru (belum pernah sebelumnya) menanam jagung sehingga diakui kurang maksimal dalam mengelola. Karena kurang pengetahuan terkait pengelulaan dan kurang dalam segi financial (modal), sehingga hasil dari penanaman jagung kurang maksimal (diluar ekspektasi). Menurut Informan Petani sangat berharap penanaman jagung memberikan nilai lebih secara ekonomi, namun pada prosesnya ketika petani menanam jagung dengan modal pinjaman dari bank, ketika panen mereka membayar hutang, dan akhirnya tersisa sedikit keuntungan dari sisa uang membayar pinjaman bank.

Petani lebih cenderung menjual langsung di gudang ketimbang menjualnya lewat calo. Dengan modal 1 jutaan hasil yang didapat petani hanya sekitar 3.5 jt. Pihak pengelolola gudang jagung beserta pemerintah menentukan harga jagung. Sebagian besar Informan tidak tahu siapa yang 
menentukan harga jagung. beberapa dari Informan memperkirakan penentuan harga jagung adalah mekanisme pasar. Ada Standar harga dari pemerintah, tapi informan tidak tahu. Lahan baru yang dibuka oleh petani, adalah lahan dengan status tanah lahan dengan ijin pengelolaan bukan lahan yang merupakan hak milik. Ada pula petani yang melakukan sistem bagi hasil dengan pihak pemilik tanah. Sampai saat ini belum ada lahan yang ditutup akibat pelanggaran pengelolaan lahan.

Dari pengakuan Informan, Selalu ada kelangkaan pupuk yang terjadi tiap tahun. Masyarakat cenderung menerima kebijakan terkait distribusi pupuk meski dirasa tidak puas. Masyarakat terkadang / seringkali harus menutupi kebutuhan pupuk dengan membeli pupuk non subsidi, meski harganya mahal. Harga pupuk non subsidi bisa 2 kali lipat harga pupuk subsidi, hal ini dirasa sangat berat oleh Informan. Sempat dilakukan demonstrasi terkait kelangkaan pupuk oleh kelompokkelompok kepemudaan yang menuntut diselesaikannya permasalahan terkait harga dan kelangkaan tersebut. Selain permasalahan malasah pupuk, masyarakat berharap diadakannya pelatihan atau edukasi dibidang pertanian khususnya pertanian jagung, untuk memaksimalkan hasil pertanian di daerah mereka.

\section{B. Dampak Sosial Peningkatan Jumlah Ladang Jagung di Kecamatan Lopok}

Program penanaman jagung yang digalakkan oleh pemerintah digadang-gadang mampu meningkatkan kesejahteraan pada petani di Kabupaten Sumbawa. Program yang berlangsung sejak 5 tahun silam pada tahun 2016 berdampak pada dibukanya lahan baru untuk menambah komoditas pertanian ini. 5 tahun berlangsung program ini belum memperlihatkan hasil yang signifikan, petani yang terbiasa menanam tanaman seperti padi, kedelai dan kacang hijau merasa sulit untuk beradaptasi dengan tanaman baru yang tentunya membutuhkan adaptasi untuk mendapatkan hasil yang maksimal. Petani yang biasanya menanam kedelai di lahan persawahannya sehabis musim tanam padi mengira kebutuhan air pada tanaman jagung sama. Nyatanya ini menjadi faktor utama yang menyebabkan kurang maksimalnya hasil pertanian. Hal ini menunjukkan petani tidak mendapatkan penyuluhan yang baik dari pemerintah diawal-awal program.

Selain persoalan adaptasi terhadap jenis tanaman baru, faktor pengelolaan keuangan juga menjadi faktor yang tidak kalah pentingnya mempengaruhi efektifitas pertanian. Untuk memulai dan mengelola pertanian tentunya petani membutuhkan modal yang cukup. Dari hasil wawancara yang dilakukan seorang informan yang sehari harinya berprofesi sebagai petani mengaku dengan modal 1 jutaan hasil yang didapat petani hanya sekitar 3.5 juta dengan asumsi keuntungan bersih sekitar 2.5 juta rupiah. Dimana Kendala yang dialami oleh petani adalah apabila pengelolaan tidak efisien maka biaya akan membengkak, misalnya penggunaan pupuk non subsidi yang dikerenakan distribusi pupuk yang kurang merata, atau kekurangan pupuk subsidi yang beredar. Sejumlah petani mengaku, jumlah lahan yang dilaporkan oleh dinas pertanian tidak sesuai dengan jumlah lahan sesungguhnya, sehingga ketika pembagian pupuk bersubsidi selalu mengalami kekurangan dan kelangkaan pupuk. Masalah kelangkaan pupuk adalah hal serius bagi para petani. Harga pupuk non subsidi dua kali lipat dari pupuk subsidi. Satu sak pupuk urea bersubsidi Rp. 120.000,- sampai Rp.130.000,- sedangkan harga pupuk non subsidi bisa mencapai Rp. 350.000,- sampai Rp. 360.000,-. Banyaknya selisih harga pupuk ini tentunya sangat berat dirasakan oleh para petani.

Pada perkembangan selanjutnya petani berusaha untuk menngkatkan produksi pertaniannya dengan menambah jumlah lahan pertaniannya. Penambahan jumlah lahan dilakukan dengan jalan melakukan perambahan hutan, tanaman Jati tebang dan digantikan dengan tanaman pangan, seperti padi dan jagung. Tanaman padi ditujukan untuk mengganti kekurang stok beras untuk kebutuhan konsumsi, sedangkan tanaman jagung ditujukan untuk meningkatkan jumlah komoditas jagung, dengan tujuan untuk dijual ke gudang-gudang jagung. 


\section{Bentuk Hegemoni Korporasi Terhadap Petani dan Pemerintah.}

Besarnya pengaruh korporasi dalam industry pertanian jagung di sumbawa bisa dilihat dari bentuk hegemoni yang terjadi. Pertama hegemoni korporasi terhadap petani sebagai penyedia utama komoditas jagung. Kedua hegemoni korporasi terhadap pemerintah yang tidak mampu mengontrol sepenuhnya mekanisme pasar, dalam hal ini mekanisme pasar terkait komoditas jagung. Pada bagian ini penulis akan mengulas satu persatu bentuk hegemoni yang didapatkan selama proses eksplorasi penelitian. Petani Jagung di kec. Lopok menerima dirinya sebagai tingkat terendah dalam piramida industry Jagung. Petani tidak menyadari eksploitasi terhadap lahan dan tenaga yang digunakan untuk meningkatkan jumlah komoditas Jagung, petani hanya memahami bahwa upaya peningkatan produksi jagung dimaksudkan untuk meningkatkan taraf hidupnya. Hal lain dari bentuk hegemoni korporasi terhadap petani jagung adalah Ketika menjual hasil pertanian petani tidak punya pilihan lain selain menjual hasil panennya pada gudang-gudang jagung yang ada, tanpa adanya usaha lain untuk mengolah jagung menjadi komoditas yang memiliki nilai jual lebih tinggi, misalnya mengolah jagung sebagai bahan baku makanan jadi atau setengah jadi yang siap dijual langsung pada konsumen.

Indikasi lain dari bentuk hegemoni korporasi terhadap adalah ketika petani menjual hasil panen dengan standar harga yang petani juga tidak paham berapa sebenarnya harga standar jagung. Hal ini memungkinkan calo atau bahkan mungkin pihak gudang memainkan harga diluar harga standar. Kondisi petani juga diperparah dengan terjadinya kelangkaan pupuk. Saat terjadi kelangkaan pupuk, petani hanya bisa menerima begitu saja tanpa solusi yang baik dari pemerintah, akhirnya petani tetap harus membeli pupuk non subsidi yang berdampak pada membengkaknya biaya produksi. Meski beberapa kali dilakukan aksi protes oleh LSM dan organisasi kepemudaan yang resah dengan kondisi petani, namun aksi protes tersebut tidak diikuti dengan edukasi terhadap masyarakat tentang sejauhmana bentuk-bentuk hegemoni korporasi tersebut merugikan para petani.

Hegemoni korporasi berikutnya adalah terhadap pemerintah tertidak berdaya menghadapi mekanisme pasar. Pemerintah tidak mampu melindung petani dengan memberikan standar harga komoditas jagung (atau mungkin karena kurangnya penyuluhan kepada petani), karena terbukti pada beberapa kasus bahkan petani tidak paham nominal sebenarnya dari standar harga jagung. Indikasi berikutnya pemerintah tidak mampu menstabilkan stok pupuk subsidi, hal ini tentunya disebabkan oleh banyak faktor. 1. Data jumlah dan luas lahan yang tidak sesuai dengan laporan yang dianggarkan untuk pengadaan pupuk subsidi, 2. Pembukaan lahan baru yang tidak terkontrol mengakibatkan meningkatnya kebutuhan akan pupuk. 3. Kemungkinan adanya pihak yang menimbun pupuk subsidi, dan kemudian menjualnya dengan harga tinggi kepada petani.

\section{KESIMPULAN}

Hasil penelitian ini menunjukkan dampak sosial terhadap petani berupa kesulitan adaptasi petani terhadap komoditi pertanian yang baru dikembangkan. Dampak selanjutnya berupa perubahan perilaku petani yang cenderung melakukan pembalakan terhadap hutan. Adapun bentuk hegemoni koorporasi yang terjadi di Sumbawa antara lain; Pertama hegemoni korporasi terhadap petani sebagai penyedia utama komoditas jagung. Kedua hegemoni korporasi terhadap pemerintah yang tidak mampu mengontrol sepenuhnya mekanisme pasar. Petani di Sumbawa tidak menyadari eksploitasi terhadap lahan dan tenaga yang digunakan pihak korporasi untuk meningkatkan jumlah komoditas Jagung. Petani hanya memahami bahwa upaya peningkatan produksi jagung dimaksudkan untuk meningkatkan taraf hidupnya. Petani menganggap program penanaman jagung merupakan bagian dari program peningkatan ekonomi dari pemerintah daerah tanpa menyadari kepentingan koorporasi dibalik program ini. 


\section{DAFTAR PUSTAKA}

Meleong, Lexy. 2002. Metode Penelitian Kualitatif . Bandung: Remaja Rosda Karya.

Narwoko, J Dwi dan Suyanto, Bagong. 2011. Sosiologi; Teks, Pengantar dan Terapan. Jakarta: Prenada Media Grup.

Poloma, Margaret M. 2004. Sosiologi Kontemporer. Jakarta ; PT Rajagrafindo Persada.

Ritzer, George. 2012. Teori Sosiologi dari Sosiologi Klasik Sampai Perkembangan Terakhir Postmodern. Yogyakarta: Pustaka Pelajar

Setiadi, Elly M dan Kolip, Usman. 2011. Pengantar Sosiologi, Pemahaman Fakta Dan Gejala Permasalahan Sosial: Teori, Aplikasi, Dan Pemecahannya. Jakarta: Kencana

Slamet. Y. 2006. Metode Penelitian Sosial. Surakarta: UNS Press

Soekanto, Soerjono. 2012. Sosiologi Suatu Pengantar. Jakarta: Rajawali Pers

Sugiyono. 2011. Metode Penelitian Kuantitatif, Kualitatif, Dan R \& D. Bandung: Alfabeta

Susilo, Rahmad. K. Dwi. 2008. 20 Tokoh Sosiologi Modern: Biografi Para Peletak Sosiologi Modern. Jogjakarta: Ar-Ruzz Media

Tarpin, Laurentius. 2008. Humanisme dan Humaniora: Relevansinya Bagi Pendidikan. hlm. 341-360. Dalam Bambang Sugiharto (edt.). Jogjakarta: Jalasutra. 